\title{
Recent Advances in Targeting the EGFR Signaling Pathway for the Treatment of Metastatic Colorectal Cancer
}

\author{
Yuji Miyamoto ${ }^{1}$, Koichi Suyama ${ }^{2}$ and Hideo Baba ${ }^{1, *}$ \\ 1 Department of Gastroenterological Surgery, Graduate School of Medical Sciences, Kumamoto University, \\ 1-1-1 Honjo, Kumamoto 860-8556, Japan; miyamotoyuji@gmail.com \\ 2 Cancer Center, Kumamoto University Hospital, Kumamoto 860-8556, Japan; kou_susan@yahoo.co.jp \\ * Correspondence: hdobaba@kumamoto-u.ac.jp; Tel.: +81-96-373-5212; Fax: +81-96-371-4378
}

Academic Editor: Peter J. K. Kuppen

Received: 7 March 2017; Accepted: 28 March 2017; Published: 2 April 2017

\begin{abstract}
Outcomes for metastatic colorectal cancer (mCRC) patients have been improved by treatment with anti-epidermal growth factor receptor (anti-EGFR) antibodies, particularly when combined with predictive biomarkers to select patients lacking RAS mutations. New technologies such as liquid biopsy and next-generation sequencing have revealed that potential mechanisms of resistance to anti-EGFR therapies act through acquired mutations of KRAS and the EGFR ectodomain. Mutations in cross-talking molecular effectors that participate in downstream EGFR signaling are also negative predictors for anti-EGFR therapy. In the current review, we describe recent advances in anti-EGFR therapy and discuss new treatment strategies to target downstream RAS-MAPK signaling in $\mathrm{mCRC}$.
\end{abstract}

Keywords: metastatic colorectal cancer; epidermal growth-factor receptor signaling (EGFR); chemotherapy; secondary resistance

\section{Introduction}

In recent decades, significant improvements have been seen in the survival of patients with metastatic colorectal cancer (mCRC). This has been driven to a large extent by the approval of new drugs, including irinotecan, oxaliplatin, capecitabine, several humanized monoclonal antibodies that target either vascular endothelial growth factor (VEGF; bevacizumab, aflibercept, and ramucirumab) or the epidermal growth factor receptor (EGFR; cetuximab and panitumumab), and most recently, regorafenib and trifluridine/tipiracil (TAS-102) [1-13]. Clinical benefit from these drugs is now well established for patients with mCRC, with median overall survival (OS) of over 30 months (M) [14-16]. In addition, a number of studies have focused on the identification of more reliable and specific predictive biomarkers for choosing the most appropriate treatment for an individual patient. The only established biomarker for the treatment of mCRC patients is tumor RAS mutational status, which is a negative predictive marker for anti-EGFR therapy [17]. Currently, BRAF mutational testing is also recommended by the National Comprehensive Cancer Network (NCCN) [18] and the European Society for Medical Oncology (ESMO) [19].

Unlike anti-VEGF therapy, the mechanisms of resistance in anti-EGFR therapy are well-studied, as are drugs inhibiting downstream RAS-MAPK signaling. Indeed, several recent clinical trials targeting RAS signaling have shown promising activity in chemorefractory mCRC. In this review, we focus on recent clinical and preclinical studies of EGFR inhibitors, their resistance mechanisms, and new downstream inhibitors of the EGFR pathway. 


\section{Clinical Advances in Anti-EGFR Antibodies}

Cetuximab and panitumumab are both monoclonal antibodies directed against the extracellular domain of the EGFR, which block ligand binding and lead to inhibition of the downstream RAS-RAF-MEK-ERK signaling pathway. Several randomized clinical trials have established the effectiveness of both drugs in combination with fluorouracil (5-FU) plus irinotecan (FOLFIRI) [8,20] and 5-FU plus oxaliplatin (FOLFOX) $[10,21]$ for patients with wild-type RAS mCRC. The differences between cetuximab and panitumumab might be derived from their different protein class characteristics or species (cetuximab is $13 \%$ mouse and $87 \%$ human, panitumumab is $100 \%$ human) [22]. As an IgG1 antibody, cetuximab exerts additional antitumor effects by mediating antibody-dependent cellular cytotoxicity [23]. However, the significance of this effect is not fully understood. The ASPECCT study [24], a phase III randomized controlled trial, indicated that panitumumab was non-inferior to cetuximab and that these agents provided a similar OS benefit in patients with chemotherapy-refractory wild-type KRAS exon $2 \mathrm{mCRC}$. The primary endpoint, median OS was $10.4 \mathrm{M}$ in the panitumumab group and $10.0 \mathrm{M}$ in the cetuximab group (hazard ratio, $\mathrm{HR}=0.97,95 \%$ confidence interval, $\mathrm{CI}=0.84-1.11, p<0.0007$ for non-inferiority). These results also showed that the incidence of grade 3 or 4 hypomagnesemia was greater in patients receiving panitumumab $(7 \%)$ than in those receiving cetuximab (3\%), although the incidence of severe skin toxicities was similar in the two groups.

\section{The Effect of RAS Status on Anti-EGFR Therapies}

The search for a predictive biomarker for anti-EGFR therapies was initially directed toward EGFR expression, which has been reported to be increased in $49 \%$ to $82 \%$ of mCRC [25,26]. Anti-EGFR therapies inhibit downstream signaling pathways, but EGFR expression status, as assessed using immunohistochemistry, does not predict treatment efficacy $[27,28]$. Data from the BOND study indicated that the intensity of immunohistochemical EGFR staining in colorectal tumor cells did not correlate with the objective response rate (ORR) to cetuximab [29]. Subsequently, mutations conferring resistance to anti-EGFR therapies were identified in codons 12 and 13 of exon 2 of the KRAS gene, which result in constitutive activation of the RAS-RAF-MEK-ERK pathway [8,21,30,31]. Activating mutations in KRAS are detected in approximately $40 \%$ of mCRC [31], with good concordance between the primary tumors and matched distant metastases [32,33].

More recent studies have found that resistance to anti-EGFR therapy can also be mediated by lower-frequency mutations in KRAS exon 3 or 4 , or in NRAS exon 2,3 , or $4[11,32,34]$. Exclusion of patients with any $R A S$ mutation identifies a population that is more likely to benefit from anti-EGFR therapies [35]. In the PRIME trial [33], 17\% of patients without mutations in KRAS exon 2 did have mutations in KRAS exon 3 or 4, or in NRAS exon 2,3, or 4 . All of these RAS mutations predicted a lack of response to panitumumab, and in fact, their presence was associated with inferior progression-free survival (PFS) and OS in patients receiving panitumumab plus FOLFOX compared with FOLFOX alone. Median OS was 25.8 M versus 20.2 M ( HR $=0.77,95 \% \mathrm{CI}=0.64-0.94, p=0.009)$ in wild-type RAS populations, in favor of the combination of panitumumab and FOLFOX. Similar results were presented for all RAS genotypes in the CRYSTAL [36] and OPUS [37] trials, in which randomized patients received first-line cetuximab in combination with FOLFIRI or FOLFOX respectively [38]. In addition, a meta-analysis of nine randomized controlled trials of anti-EGFR antibodies for mCRC demonstrated the predictive value of RAS mutational profiles for both PFS and OS [35]. These results indicate that the anti-EGFR antibodies should be restricted to $\mathrm{mCRC}$ patients whose tumors lack all KRAS and NRAS mutations.

\section{KRAS ${ }^{\mathrm{G} 13 \mathrm{D}}$ Mutation}

Preclinical studies and retrospective data from phase III trials suggest that patients with KRAS ${ }^{G 13 D}$ mutant tumors might benefit from cetuximab. De Roock et al. reported that patients carrying the $K R A S^{G 13 D}$ mutation and treated with cetuximab had prolonged $\mathrm{OS}(\mathrm{HR}=0.50,95 \% \mathrm{CI}=0.31-0.81$, 
$p=0.005)$ and PFS (HR $=0.51,95 \% \mathrm{CI}=0.32-0.81, p=0.004)$ compared with patients whose tumors harbored other KRAS mutations [39]. Another retrospective analysis was performed on a pooled data set from the CRYSTAL and OPUS studies [40]. Within KRAS mutation subgroups, cetuximab plus chemotherapy versus chemotherapy alone significantly improved PFS (median, 7.4 versus $6.0 \mathrm{M}$, $\mathrm{HR}=0.47, p=0.039)$ and tumor response rate $(41 \%$ versus $22 \%$, odds ratio, $\mathrm{OR}=3.38, p=0.042)$ in patients with $K R A S^{G 13 D}$ mutant tumors. Based on these results, two prospective phase II trials were performed; however, both trials showed no activity for cetuximab monotherapy in patients with KRAS ${ }^{G 13 D}$ mutant mCRC. In the phase II ICECREAM trial [41], there was no statistically significant improvement in disease control at $6 \mathrm{M}$ for patients with $K R A S^{G 13 D}$ mutant tumors treated with either cetuximab monotherapy or cetuximab plus irinotecan. Currently, anti-EGFR therapies are not routinely recommended for patients with $K R A S^{G 13 D}$ mutant tumors.

\section{Anti-EGFR Therapies versus Bevacizumab in First Line Chemotherapy}

A highly important unresolved issue is whether the anti-VEGF bevacizumab or an anti-EGFR antibody is the optimal first-line biologic agent to be added to chemotherapy for patients with wild-type RAS mCRC. Two phase III trials, FIRE-3 [14] and CALGB/SWOG 80405 [42], and the phase II PEAK trial [43] have directly compared the addition of bevacizumab versus cetuximab or panitumumab to FOLFOX/FOLFIRI in terms of efficacy outcomes. The FIRE-3 study [14] was conducted to evaluate the superiority of FOLFIRI plus cetuximab to FOLFIRI plus bevacizumab as a first-line treatment for mCRC patients with wild-type KRAS. In patients with only wild-type $R A S$ tumors, the median OS was significantly longer with cetuximab (33.1 M versus $25.6 \mathrm{M}, \mathrm{HR}=0.70,95 \% \mathrm{CI}=0.53-0.92, p=0.011$ ), but the median PFS was almost identical (10.4 M versus $10.2 \mathrm{M}, \mathrm{HR}=0.93,95 \% \mathrm{CI}=0.74-1.17, p=0.54$ ). A similar pattern of outcomes was observed in the PEAK trial [43], primarily comparing FOLFOX plus either panitumumab or bevacizumab in patients with previously untreated, wild-type KRAS mCRC. In patients with all wild-type RAS, PFS was $13.0 \mathrm{M}$ in the panitumumab arm and $9.5 \mathrm{M}$ in the bevacizumab arm $(\mathrm{HR}=0.65,95 \% \mathrm{CI}=0.44-0.96, p=0.029)$, and median OS was $41.3 \mathrm{M}$ in the panitumumab arm and 28.9 $\mathrm{M}$ in the bevacizumab arm ( $\mathrm{HR}=0.63,95 \% \mathrm{CI}=0.39-1.02, p=0.058)$.

The phase III CALGB/SWOG 80405 trial [42] could not demonstrate a benefit for initial cetuximab versus bevacizumab in combination with either FOLFIRI or FOLFOX, even in patients with only wild-type $R A S$ tumors. In patients with wild-type $R A S$ tumors, there was no significant difference in OS and PFS between the cetuximab and bevacizumab in combination with chemotherapy. However, there was a higher response rate achieved in the cetuximab arm $(68.6 \%$ versus $53.6 \%, p<0.01)$. A meta-analysis of these randomized controlled trials supports a potential benefit of first-line EGFR inhibitors plus chemotherapy versus bevacizumab plus chemotherapy with respect to OS (HR $=0.8$, $95 \% \mathrm{CI}=0.68-0.93, p=0.004)$ and $\mathrm{ORR}(\mathrm{OR}=0.57,95 \% \mathrm{CI}=0.42-0.76)$ in patients with wild-type $R A S$ $\mathrm{mCRC}$ [44]. Another phase III trial currently in progress, PARADIGM [45], is comparing panitumumab versus bevacizumab in combination with FOLFOX.

\section{Primary Tumor Location as a Prognostic and Predictive Biomarker in mCRC}

Another topic of interest is the prognostic and predictive significance of primary tumor location in $\mathrm{mCRC}$ patients with wild-type RAS tumors. Genetic and phenotypic differences may be derived from pre-existing disparities between the left and right colon with respect to embryonic origin, blood supply, innervation, lymphatic drainage, and lumen environment. Associations between a particular marker and prognosis or response to chemotherapy have been found to be site-specific [46-49].

Recently, retrospective analyses were conducted in patients with wild-type RAS mCRC from two large phase III trials, CRYSTAL and FIRE-3, in which mCRC were classified as left-sided or right-sided [50]. In the CRYSTAL trial, patients with right-sided tumors in the FOLFIRI plus cetuximab treatment group had a significantly shorter PFS and OS compared with equivalent patients with left-sided tumors (PFS: 8.1 M versus 12.0 M, HR =1.77, 95\% CI = 1.08-2.91, $p=0.02$; OS: $28.7 \mathrm{M}$ versus $18.5 \mathrm{M}, \mathrm{HR}=1.93,95 \% \mathrm{CI}=1.24-2.99, p=0.003)$. Furthermore, the addition of cetuximab to FOLFIRI 
in patients with left-sided tumors significantly improved PFS (12.0 M versus $8.9 \mathrm{M}, \mathrm{HR}=0.50,95 \%$ $\mathrm{CI}=0.34-0.72, p<0.001)$, OS (28.7 M versus $21.7 \mathrm{M}, \mathrm{HR}=0.65,95 \% \mathrm{CI}=0.50-0.86, p=0.002)$, and ORR $(72.5 \%$ versus $40.6 \%$, OR $=3.99,95 \% \mathrm{CI}=2.40-6.62, p<0.001)$, as expected based on the overall population. In patients with right-sided tumors, however, the addition of cetuximab conferred more limited benefits on PFS (8.1 M versus 7.1 $\mathrm{M}, \mathrm{HR}=0.87,95 \% \mathrm{CI}=0.47-1.62, p=0.66)$, OS (18.5 M versus $15.0 \mathrm{M}, \mathrm{HR}=1.8,95 \% \mathrm{CI}=0.65-1.81, p=0.76)$, and $\mathrm{ORR}(42.4 \%$ versus $33.3 \%$, $\mathrm{OR}=1.45$, $95 \% \mathrm{CI}=0.58-3.64, p=0.43$ ).

Results consistent with these were obtained from the FIRE-3 trial. Patients with left-sided tumors who received FOLFIRI plus cetuximab had significantly longer OS than those receiving FOLFIRI plus bevacizumab (38.3 $\mathrm{M}$ versus $28.0 \mathrm{M}, \mathrm{HR}=0.63,95 \% \mathrm{CI}=0.48-0.85, p<0.002)$, but with no significant differences in PFS or ORR. In contrast, among patients with right-sided tumors, there were no significant differences in OS, PFS, or ORR for FOLFIRI plus cetuximab versus FOLFIRI plus bevacizumab. Moreover, multivariable analyses revealed that, in both studies, there was a significant interaction between primary tumor location and treatment modality for OS of patients with wild-type RAS tumors.

These results confirm the prognostic value of primary tumor location in wild-type $R A S$ populations, and further suggest an interaction between tumor location and response to treatment. Right-sided tumors do not significantly benefit from the addition of cetuximab, in contrast to a marked benefit for left-sided tumors [48,51]. This difference may be derived from the molecular/genetic background, and/or from embryological or epidemiological factors. For example, right-sided tumors are associated with $B R A F$ mutation, DNA hypermethylation (the $\mathrm{CpG}$ island methylator phenotype, CIMP), and hypermutated consensus molecular subtypes [52]. Comprehensive molecular and genetic analysis of specimens derived from phase III trials is needed to identify biological differences between right- and left-sided colons.

\section{Resistance Mechanism to Anti-EGFR Therapies}

Even among patients with wild-type RAS mCRC that initially responds to anti-EGFR therapies, the majority will eventually experience disease progression. This implies acquired resistance to anti-EGFR therapy. Therefore, multiple studies have focused on exploring resistance mechanisms, and it seems that several biomarkers and pathways are involved in the development of resistance to anti-EGFR therapy. The two principal downstream effectors of EGFR activation are the RAS-MAPK pathway and the PI3K-AKT-mTOR pathway, both of which control cell growth and proliferation (Figure 1) [53]. Several investigators have assessed circulating tumor DNA (ctDNA) in the blood of mCRC patients during anti-EGFR therapy and found that undetectable low-frequency KRAS-mutant clones may be selected by anti-EGFR treatment [54-57].

Using BEAMing technology, which can detect somatic mutations in small amounts of ctDNA, Morelli et al. found that acquired mutations in KRAS were seen in $44 \%$ of patients initially characterized as having wild-type KRAS tumors, following the development of resistance to anti-EGFR therapy [54]. Interestingly, atypical KRAS codon 61 and 146 mutations were more frequent among these newly diagnosed mutations. In addition, the mutations were detectable as low-allele-frequency clones in $35 \%$ of patients with plasma mutations, suggesting that they were already present in the treatment-naïve primary tumors. The presence of low-frequency KRAS mutations in these patients was correlated with a poorer response to anti-EGFR treatment. These data suggest that a high-sensitivity mutation detection technique that provides quantitative information about the presence of mutant alleles in the gene of interest would allow for the selection of patients most likely to benefit from anti-EGFR treatment.

A second mechanism of resistance entails mutations in the extracellular domain (ECD) of EGFR that prevent binding of the drug to the receptor. Although secondary EGFR mutation is rarely detected after resistance to anti-EGFR therapies, Montagut and colleagues discovered an acquired EGFR mutation, S492R, and proved its association with acquired resistance to cetuximab in mCRC [58]. The S492R mutation is within the EGFR ectodomain, and a bulky side chain at this position could 
interfere with cetuximab binding. The EGFR ${ }^{S 492 R}$ mutation was detected in two of ten patients who experienced disease progression after a prior response to cetuximab with chemotherapy. Interestingly, one patient with cetuximab resistance harboring the EGFR ${ }^{S 492 R}$ mutation responded to treatment with panitumumab. This result was also confirmed in vitro by using NIH3T3 fibroblasts expressing wild-type or S492R-mutant EGFR. In cells carrying the S492R mutation, only panitumumab blocked the activation of EGFR. Overall, these findings identified the S492R mutation as a mechanism of acquired but not primary resistance to cetuximab.

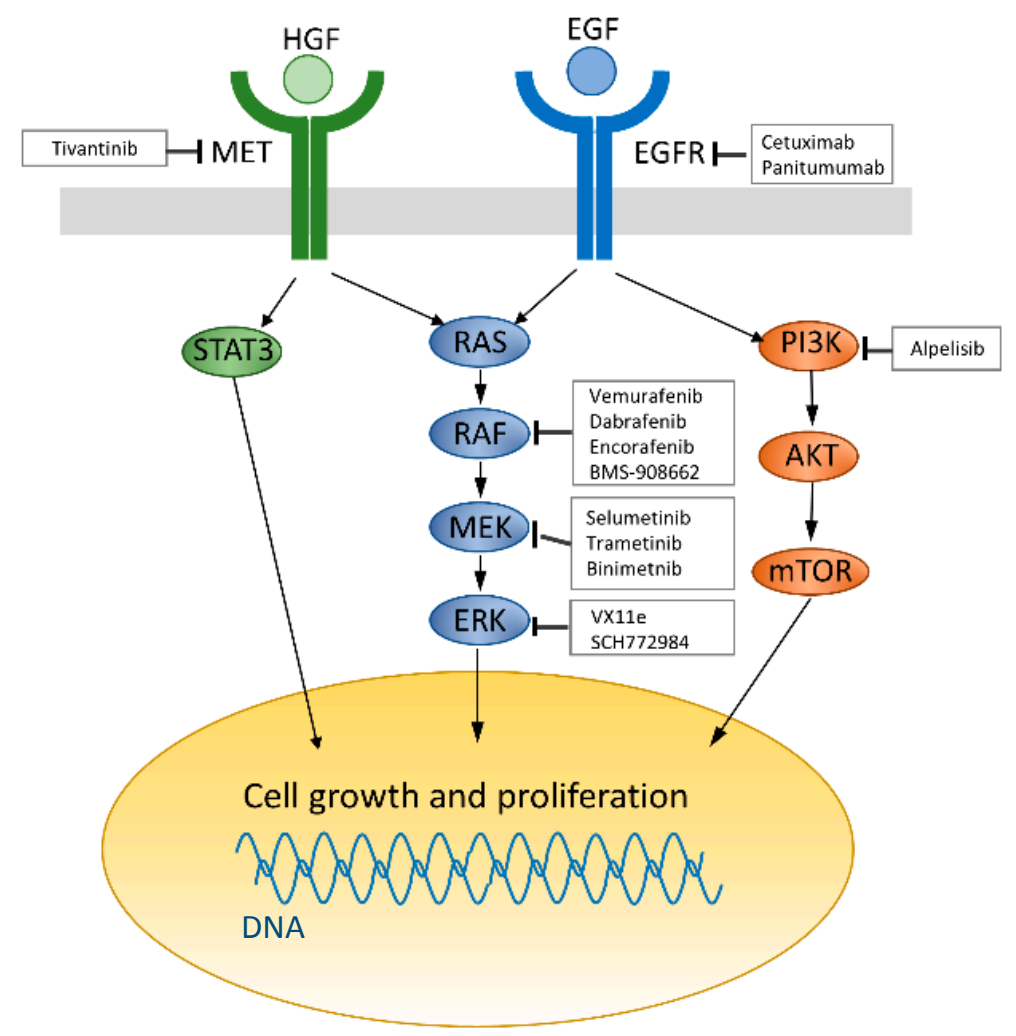

Figure 1. Current strategies for targeting the epidermal growth factor receptor (EGFR) pathway. EGF receptors (Blue) activate survival signaling pathways including RAS/MAPK and PI3K/AKT signaling pathway leading to cell growth and proliferation. HGF/MET (green) signaling also promotes cell growth and proliferation through RAS/MAPK and STAT3 phosphorylation. Regular arrow: activates, Arrow ending with a straight line: inhibits.

Some new EGFR inhibitors appear to overcome resistance to cetuximab or panitumumab that is due to the emergence of mutations in the EGFR ECD. Sym004 is a novel 1:1 mixture of two non-overlapping anti-EGFR monoclonal antibodies that target different epitopes of the EGFR ECD. A unique feature of Sym004 is its ability to mediate rapid EGFR internalization and subsequent degradation via EGFR cross-linking [59-61]. Preclinical studies with Sym004 showed superior antitumor activity as compared with cetuximab or panitumumab, as well as activity in models of acquired cetuximab resistance [60,62]. In a phase I study of mCRC patients whose tumors were resistant to cetuximab or panitumumab, Sym004 demonstrated a $44 \%$ tumor shrinkage rate and a $13 \%$ response rate [59]. It is currently being tested in a dose-optimization, phase II study in refractory mCRC patients (NCT02083653), as well as in combination with FOLFIRI (NCT02568046) [63].

MM-151 is a combination of three fully human IgG1 monoclonal antibodies that can simultaneously engage distinct, non-overlapping epitopes on the EGFR [64,65]. MM-151 was designed using a systems biology approach to substantially improve on the mechanisms that enable potent EGFR antagonism, EGFR downregulation, and immune effector function. In a phase I study 
examining MM-151 as a monotherapy or in combination with irinotecan, three mCRC patients achieved partial responses, and eight had stable disease for more than $4 \mathrm{M}$ on single-agent MM-151 [66]. The most common adverse events were toxicities related to the EGFR pathway, including rashes (70\%), hypomagnesemia (24\%), fatigue, dry skin, and diarrhea (21\%). After MM-151 treatment, liquid biopsies of patients with EGFR ECD mutations at baseline showed decreased or stabilized EGFR ECD mutant DNA concentrations that paralleled response assessments using radiological methods.

Activation of the PI3K/AKT/mTOR signaling pathway has also been implicated as an important mechanism in the resistance to EGFR inhibitors. PIK3CA mutations occur at a prevalence of $10 \%-20 \%$, are mainly located at hot spots in exons 20 and 9, and constitutively activate downstream signaling [67]. Retrospective studies have investigated the potential role of PIK3CA mutations as predictors of resistance to anti-EGFR treatment in mCRC patients, with conflicting results. A systematic review was conducted to evaluate the association between PIK3CA mutations and resistance to anti-EGFR therapy in $\mathrm{mCRC}$ [68]. The results showed a trend of worse PFS and a significantly shorter OS (HR $=1.43,95 \%$ $\mathrm{CI}=1.02-2.00)$ compared with patients with wild-type tumors. However, a large prospective study is needed to confirm this result.

Additional possible mechanisms of resistance to anti-EGFR therapies have been proposed in patients with RAS and BRAF wild-type mCRC [69]. Genetic aberrations of the receptor tyrosine kinases $c-M E T$ and $E R B B 2$ are identified as the bypass mechanisms for acquired resistance to anti-EGFR therapies. c-MET and its ligand HGF have been previously implicated in both primary and acquired resistance to anti-EGFR therapies. For example, among 103 patients with KRAS wild-type mCRC who received anti-EGFR therapies, those with high serum levels of HGF had shorter PFS (4.4 M versus $6.4 \mathrm{M}, p=0.001)$ and OS (8.0 M versus 15.3 months; $p=0.001)$ compared with those with low levels of HGF [70]. Another study demonstrated that c-MET overexpression significantly correlated with shorter PFS ( $3 \mathrm{M}$ versus $5 \mathrm{M}, p=0.018$ ) and OS (11 M versus $10 \mathrm{M}, p=0.037$ ) compared with low /normal expression [71]. Whole-exome analysis revealed that the c-MET copy number was increased in CRC tissues from patients who developed resistance to anti-EGFR therapies [72]. Moreover, the c-MET amplification locus could be detected in circulating tumor DNA, suggesting that the early initiation of c-MET inhibitors in those patients who respond to anti-EGFR therapies and do not display emergence of KRAS mutations in blood tests during anti-EGFR therapies [72].

ERBB2 gene amplifications were also described as drivers of acquired resistance to anti-EGFR therapies in RAS and BRAF wild-type mCRC. Yonesaka et al. showed that activation of HER2 signaling in cancer cells, through either HER2 gene amplification or upregulation of the HER2/HER3 ligand heregulin, is enabled to acquire the resistance to anti-EGFR therapies [73]. Large xenograft cohorts from patient-derived demonstrated that ErbB-2 amplification was shown in cetuximab-resistant patients and in RAS/BRAF/PI3KCA wild-type patients [74]. Moreover, HER2 amplification was detected in ctDNA from patients with $\mathrm{mCRC}$ and acquired resistance to anti-EGFR antibody therapy [75,76]. These data suggest that combination therapies against EGFR and ERBB2 in RAS wild-type tumors might be useful.

\section{BRAF Mutation in Colorectal Cancer}

$B R A F$ is a serine/threonine protein kinase that plays an important role in the EGFR-mediated $M A P K$ pathway [77], where it is activated by the small GTPase, $R A S$. The BRAF gene is somatically mutated in approximately $5 \%$ to $10 \%$ of mCRC [78,79]. The most common BRAF mutation in CRC is the V600E alteration, which causes a constitutive activation of the MAPK pathway, independent of RAS activity [80]. In addition, BRAF mutations are mutually exclusive with RAS mutations [81]. The $B R A F^{V 600 E}$ mutation is associated with proximal location, greater age, female gender, microsatellite instability (MSI), CIMP, high grade, and mucinous histology in colorectal cancer [81]. BRAF mutations have also been shown to be associated with poor prognosis in mCRC. Moreover, $B R A F$ mutations also appear to have predictive value, with increasing evidence that $B R A F$ mutations predict a lack of benefit from anti-EGFR therapy, even in wild-type RAS mCRC. Currently, consensus-based guidelines 
from NCCN [18] and ESMO [19] both recommend avoiding the use of cetuximab or panitumumab for patients with $B R A F$-mutated cancers.

\section{Combination Therapies with BRAF Inhibitors}

$B R A F$ mutations are commonly identified in melanoma, in which the BRAF mutation rate is more than $60 \%$, offering hope that inhibition of BRAF kinase activity could benefit melanoma patients. The BRAF inhibitors, vemurafenib and dabrafenib, have shown response rates of up to approximately $50 \%$ in metastatic melanoma patients with the $B R A F^{V 600 E}$ mutation $[82,83]$. However, BRAF inhibitor monotherapies appear to be ineffective in $B R A F^{V 600 E}$ mutant $\mathrm{mCRC}$, with a response rate of approximately 5\% [79]. Accumulating evidence suggests that these BRAF inhibitors induce negative feedback reactivation of EGFR, which in turn activates MAPK via CRAF and RAS [84-86].

Preclinical studies indicated that combinations of BRAF inhibitors with inhibitors of upstream receptors show an improved efficacy in BRAF-mutated mCRC [87]. Based on these data, BRAF inhibitor combinations have been evaluated in clinical trials for patients with $B R A F$-mutated mCRC in recent years, and are showing signs of improved efficacy compared with RAF inhibition alone (Table 1) [85,88-90]. Kopetz and colleagues presented the results of a phase II/III trial in which they randomly assigned 49 patients with $B R A F$-mutated mCRC to receive irinotecan, cetuximab, and vemurafenib and 50 to receive only irinotecan and cetuximab [91]. Patients receiving the three-drug regimen showed significantly longer PFS compared with those receiving the doublet regimen $(4.4 \mathrm{M}$ versus $2.0 \mathrm{M}, \mathrm{HR}=0.42,95 \% \mathrm{CI}=0.26-0.66, p=0.0002)$. Notably, Grade 3 or 4 toxicities in patients in the three-drug group included neutropenia (28\%), diarrhea $(22 \%)$, anemia $(13 \%)$, and nausea $(15 \%)$. However, these are similar to a prior second line study of cetuximab plus irinotecan. These results for combination therapy including a BRAF inhibitor are consistent with earlier preclinical studies.

Despite combination therapy initially preventing the development of acquired resistance in patients with $B R A F$-mutated $\mathrm{mCRC}$, these patients ultimately develop secondary resistance to treatment and experience disease progression. Alterations in MAPK pathway genes, including KRAS amplification, BRAF amplification, and a MEK1 mutation, were found in resistant tumors and were not present in matched pretreatment tumors [92]. Importantly, an ERK inhibitor retained the ability to suppress the MAPK pathway and could overcome each of the identified acquired resistance mechanisms in BRAF-mutated mCRC [92]. These results suggest that ERK inhibitors could be important components of future therapeutic strategies for $B R A F$-mutated $\mathrm{mCRC}$, either alone or in combination with BRAF and EGFR inhibitors. 
Table 1. Clinical trials of drugs targeting EGFR downstream pathway.

\begin{tabular}{|c|c|c|c|c|c|c|c|c|c|}
\hline Strategy & Treatment & Genomic Profile & Phase & $\mathbf{N}$ & ORR (\%) & PFS (M) & OS (M) & Clinical Development & Reference \\
\hline BRAF monotherapy & Vemurafenib & BRAFmut & I/II & 21 & 5 & 2.1 & 7.7 & Complete & NCT00405587 [93] \\
\hline BRAF monotherapy & Vemurafenib & BRAFmut & II & 10 & 0 & 4.5 & 9.3 & Complete & NCT01524978 [94] \\
\hline BRAF + MEK & Dabrafenib + Trametinib & BRAFmut & I/II & 43 & 12 & 3.5 & $(-)$ & Complete & NCT01726738 [88] \\
\hline BRAF + EGFR & Vemurafenib + Cetuximab & BRAFmut & II & 27 & 4 & 3.7 & 7.1 & Complete & NCT01524978 [94] \\
\hline BRAF + EGFR & Vemurafenib + Panitumumab & BRAFmut & Pilot & 15 & 13 & 3.2 & 7.6 & Complete & NCT01791309 [89] \\
\hline BRAF + EGFR & Encorafenib + Cetuximab & BRAFmut & II & 50 & 22 & 4.2 & 12.4 & Ongoing & NCT01719380 [90] \\
\hline BRAF + EGFR & Dabrafenib + Panitumumab & BRAFmut & I/II & 20 & 10 & 3.4 & $(-)$ & Ongoing & NCT01750918 [85] \\
\hline BRAF + EGFR & BMS-908662 + Cetuximab & Kras mut or BRAF mut & I/II & $17^{*}$ & $(-)$ & $(-)$ & $(-)$ & Ongoing & NCT01086267 \\
\hline $\mathrm{BRAF}+\mathrm{EGFR}+\mathrm{CT}$ & Vemurafenib + Cetuximab + irinotecan & BRAFmut & I & 12 & 50 & $(-)$ & $(-)$ & Ongoing & NCT01787500 \\
\hline $\mathrm{BRAF}+\mathrm{EGFR}+\mathrm{CT}$ & Cetuximab + irinotecan \pm Vemurafenib & BRAFmut & II (RCT) & $78^{*}$ & $(-)$ & $(-)$ & $(-)$ & Ongoing & NCT02164916 \\
\hline BRAF + EGFR + MEK & Dabrafenib + Panitumumab + Trametinib & BRAFmut & I/II & 83 & 18 & $(-)$ & $(-)$ & Ongoing & NCT01750918 [85] \\
\hline BRAF + EGFR \pm MEK & Encorafenib + Cetuximab \pm Binimetinib & None & III & $645^{*}$ & $(-)$ & $(-)$ & $(-)$ & Ongoing & NCT02928224 \\
\hline BRAF + EGFR + PI3K & Encorafenib + Cetuximab + Alpelisib & BRAFmut & II & 52 & 27 & 5.4 & 13.1 & Ongoing & NCT01719380 [90] \\
\hline $\mathrm{MEK}+\mathrm{CT}$ & Selumetinib + irinotecan & Kras mut or BRAF mut & II & 32 & 9 & $(-)$ & $(-)$ & Complete & NCT01116271 [95] \\
\hline MEK + EGFR & Binimetinib + Panitumumab & RAS wt or RAS mut & I/II & $90^{*}$ & $(-)$ & $(-)$ & $(-)$ & Ongoing & NCT01927341 \\
\hline MEK + EGFR & Panitumumab + Trametinib & BRAFmut & I/II & 31 & 0 & 2.8 & & Ongoing & NCT01750918 [85] \\
\hline MEK + EGFR & Trametinib + Panitumumab & KRAS BRAF wt & II & $26^{*}$ & $(-)$ & $(-)$ & $(-)$ & Ongoing & NCT02399943 \\
\hline $\mathrm{MET}+\mathrm{EGFR}+\mathrm{CT}$ & Cetuximab + irinotecan \pm Tivantinib & KRAS wt & I/II (RCT) & 60 & 45 & 8.3 & 19.8 & Complete & NCT01075048 [96] \\
\hline MEK + AKT & Selumetinib + MK-2206 & KRAS wt or KRAS mut & II & $21^{*}$ & $(-)$ & $(-)$ & $(-)$ & Ongoing & NCT01333475 \\
\hline
\end{tabular}

ORR: objective response rate; PFS: progression free survival; OS: overall survival; M: months; CT: chemotherapy; RCT: randomized control trial. * Planed sample size, (-): not reported. 


\section{Conclusions}

EGFR-targeting drugs directly affect cancer cells and may be affected by accumulating drug resistance mutations in the RAS-RAF-MEK-ERK pathway. Several clinical trials are currently underway to elucidate which treatment has the best outcome. We believe that liquid biopsy and next-generation sequencing technology will help to identify and monitor predictive biomarkers for acquired resistance to anti-EGFR therapies. One can hope that a comprehensive understanding of resistance mechanisms will contribute to developing more effective strategies to overcome acquired resistance in the future.

Acknowledgments: The authors would like to thank Edanz Editing, Minato-Ku Fukuoka City, Fukuoka, Japan for reviewing the article for language and grammar errors.

Author Contributions: Yuji Miyamoto designed and drafted the manuscript; Koichi Suyama and Hideo Baba discussed and revised the manuscript.

Conflicts of Interest: Hideo Baba received honoraria from Chugai Pharma, Bayer, Taiho Pharmaceutical, and Merk Inc. and research funding from Yakult Honsha, Chugai Pharma, Takeda, Ono Pharmaceutical, and Taiho Pharmaceutical. The other authors have no conflict of interest.

\section{References}

1. Saltz, L.B.; Cox, J.V.; Blanke, C.; Rosen, L.S.; Fehrenbacher, L.; Moore, M.J.; Maroun, J.A.; Ackland, S.P.; Locker, P.K.; Pirotta, N.; et al. Irinotecan plus fluorouracil and leucovorin for metastatic colorectal cancer. Irinotecan Study Group. N. Engl. J. Med. 2000, 343, 905-914. [CrossRef] [PubMed]

2. De Gramont, A.; Figer, A.; Seymour, M.; Homerin, M.; Hmissi, A.; Cassidy, J.; Boni, C.; Cortes-Funes, H.; Cervantes, A.; Freyer, G.; et al. Leucovorin and fluorouracil with or without oxaliplatin as first-line treatment in advanced colorectal cancer. J. Clin. Oncol. 2000, 18, 2938-2947. [CrossRef] [PubMed]

3. Cassidy, J.; Clarke, S.; Diaz-Rubio, E.; Scheithauer, W.; Figer, A.; Wong, R.; Koski, S.; Lichinitser, M.; Yang, T.-S.; Rivera, F.; et al. Randomized phase III study of capecitabine plus oxaliplatin compared with fluorouracil/folinic acid plus oxaliplatin as first-line therapy for metastatic colorectal cancer. J. Clin. Oncol. 2008, 26, 2006-2012. [CrossRef] [PubMed]

4. Hurwitz, H.; Fehrenbacher, L.; Novotny, W.; Cartwright, T.; Hainsworth, J.; Heim, W.; Berlin, J.; Baron, A.; Griffing, S.; Holmgren, E.; et al. Bevacizumab plus irinotecan, fluorouracil, and leucovorin for metastatic colorectal cancer. N. Engl. J. Med. 2004, 350, 2335-2342. [CrossRef] [PubMed]

5. Saltz, L.B.; Clarke, S.; Díaz-Rubio, E.; Scheithauer, W.; Figer, A.; Wong, R.; Koski, S.; Lichinitser, M.; Yang, T.-S.S.; Rivera, F.; et al. Bevacizumab in combination with oxaliplatin-based chemotherapy as first-line therapy in metastatic colorectal cancer: A randomized phase III study. J. Clin. Oncol. 2008, 26, 2013-2019. [CrossRef] [PubMed]

6. Van Cutsem, E.; Tabernero, J.; Lakomy, R.; Prenen, H.; Prausova, J.; Macarulla, T.; Ruff, P.; van Hazel, G.A.; Moiseyenko, V.; Ferry, D.; et al. Addition of aflibercept to fluorouracil, leucovorin, and irinotecan improves survival in a phase III randomized trial in patients with metastatic colorectal cancer previously treated with an oxaliplatin-based regimen. J. Clin. Oncol. 2012, 30, 3499-3506. [CrossRef] [PubMed]

7. Tabernero, J.; Yoshino, T.; Cohn, A.L.; Obermannova, R.; Bodoky, G.; Garcia-Carbonero, R.; Ciuleanu, T.-E.E.; Portnoy, D.C.; van Cutsem, E.; Grothey, A.; et al. Ramucirumab versus placebo in combination with second-line FOLFIRI in patients with metastatic colorectal carcinoma that progressed during or after first-line therapy with bevacizumab, oxaliplatin, and a fluoropyrimidine (RAISE): A randomised, double-blin. Lancet Oncol. 2015, 16, 499-508. [CrossRef]

8. Van Cutsem, E.; Kohne, C.H.; Hitre, E.; Zaluski, J.; Chang Chien, C.-R.; Makhson, A.; D’Haens, G.; Pinter, T.; Lim, R.; Bodoky, G.; et al. Cetuximab and chemotherapy as initial treatment for metastatic colorectal cancer. N. Engl. J. Med. 2009, 360, 1408-1417. [CrossRef] [PubMed]

9. Van Cutsem, E.; Lenz, H.J.; Kohne, C.H.; Heinemann, V.; Tejpar, S.; Melezinek, I.; Beier, F.; Stroh, C.; Rougier, P.; van Krieken, J.H.; et al. Fluorouracil, leucovorin, and irinotecan plus cetuximab treatment and RAS mutations in colorectal cancer. J. Clin. Oncol. 2015, 33, 692-700. [CrossRef] [PubMed] 
10. Douillard, J.Y.; Siena, S.; Cassidy, J.; Tabernero, J.; Burkes, R.; Barugel, M.; Humblet, Y.; Bodoky, G.; Cunningham, D.; Jassem, J.; et al. Randomized, phase III trial of panitumumab with infusional fluorouracil, leucovorin, and oxaliplatin (FOLFOX4) versus FOLFOX4 alone as first-line treatment in patients with previously untreated metastatic colorectal cancer: The PRIME study. J. Clin. Oncol. 2010, 28, 4697-4705. [CrossRef] [PubMed]

11. Douillard, J.Y.; Oliner, K.S.; Siena, S.; Tabernero, J.; Burkes, R.; Barugel, M.; Humblet, Y.; Bodoky, G.; Cunningham, D.; Jassem, J.; et al. Panitumumab-FOLFOX4 treatment and RAS mutations in colorectal cancer. N. Engl. J. Med. 2013, 369, 1023-1034. [CrossRef] [PubMed]

12. Grothey, A.; van Cutsem, E.; Sobrero, A.; Siena, S.; Falcone, A.; Ychou, M.; Humblet, Y.; Bouché, O.; Mineur, L.; Barone, C.; et al. Regorafenib monotherapy for previously treated metastatic colorectal cancer (CORRECT): An international, multicentre, randomised, placebo-controlled, phase 3 trial. Lancet 2013, 381, 303-312. [CrossRef]

13. Mayer, R.J.; van Cutsem, E.; Falcone, A.; Yoshino, T.; Garcia-Carbonero, R.; Mizunuma, N.; Yamazaki, K.; Shimada, Y.; Tabernero, J.; Komatsu, Y.; et al. Randomized trial of TAS-102 for refractory metastatic colorectal cancer. N. Engl. J. Med. 2015, 372, 1909-1919. [CrossRef] [PubMed]

14. Heinemann, V.; von Weikersthal, L.F.; Decker, T.; Kiani, A.; Vehling-kaiser, U.; Scholz, M.; Müller, S.; Link, H.; Niederle, N.; Rost, A.; et al. FOLFIRI plus cetuximab versus FOLFIRI plus bevacizumab as first-line treatment for patients with metastatic colorectal cancer (FIRE-3): A randomised, open-label, phase 3 trial. Lancet Oncol. 2014, 15, 1065-1075. [CrossRef]

15. Yamada, Y.; Takahari, D.; Matsumoto, H.; Baba, H.; Nakamura, M.; Yoshida, K.; Yoshida, M.; Iwamoto, S.; Shimada, K.; Komatsu, Y.; et al. Leucovorin, fluorouracil, and oxaliplatin plus bevacizumab versus S-1 and oxaliplatin plus bevacizumab in patients with metastatic colorectal cancer (SOFT): An open-label, non-inferiority, randomised phase 3 trial. Lancet Oncol. 2013, 14, 1278-1286. [CrossRef]

16. Loupakis, F.; Cremolini, C.; Masi, G.; Lonardi, S.; Zagonel, V.; Salvatore, L.; Cortesi, E.; Tomasello, G.; Ronzoni, M.; Spadi, R.; et al. Initial therapy with FOLFOXIRI and bevacizumab for metastatic colorectal cancer. N. Engl. J. Med. 2014, 371, 1609-1618. [CrossRef] [PubMed]

17. Waring, P.; Tie, J.; Maru, D.; Karapetis, C.S. RAS mutations as predictive biomarkers in clinical management of metastatic colorectal cancer. Clin. Colorectal Cancer 2016, 15, 95-103. [CrossRef] [PubMed]

18. National Comprehensive Cancer Network (NCCN). Guidelines Version 1. 2016 Colon Cancer; National Comprehensive Cancer Network: Washington, PA, USA, 2016.

19. Van Cutsem, E.; Cervantes, A.; Adam, R.; Sobrero, A.; van Krieken, J.H.; Aderka, D.; Aranda Aguilar, E.; Bardelli, A.; Benson, A.; Bodoky, G.; et al. ESMO consensus guidelines for the management of patients with metastatic colorectal cancer. Ann. Oncol. 2016, 27, 1386-1422. [CrossRef] [PubMed]

20. Peeters, M.; Price, T.J.; Cervantes, A.; Sobrero, A.F.; Ducreux, M.; Hotko, Y.; Andre, T.; Chan, E.; Lordick, F.; Punt, C.J.A.; et al. Randomized phase III study of panitumumab with fluorouracil, leucovorin, and irinotecan (FOLFIRI) compared with FOLFIRI alone as second-line treatment in patients with metastatic colorectal cancer. J. Clin. Oncol. 2010, 28, 4706-4713. [CrossRef] [PubMed]

21. Bokemeyer, C.; Bondarenko, I.; Makhson, A.; Hartmann, J.T.; Aparicio, J.; De Braud, F.; Donea, S.; Ludwig, H.; Schuch, G.; Stroh, C.; et al. Fluorouracil, leucovorin, and oxaliplatin with and without cetuximab in the first-line treatment of metastatic colorectal cancer. J. Clin. Oncol. 2009, 27, 663-671. [CrossRef] [PubMed]

22. Snyder, L.C.; Astsaturov, I.; Weiner, L.M. Overview of monoclonal antibodies and small molecules targeting the epidermal growth factor receptor pathway in colorectal cancer. Clin. Colorectal Cancer 2005, 5, S71-S80. [CrossRef] [PubMed]

23. Seo, Y.; Ishii, Y.; Ochiai, H.; Fukuda, K.; Akimoto, S.; Hayashida, T.; Okabayashi, K.; Tsuruta, M.; Hasegawa, H.; Kitagawa, Y. Cetuximab-mediated ADCC activity is correlated with the cell surface expression level of EGFR but not with the KRAS/BRAF mutational status in colorectal cancer. Oncol. Rep. 2014, 31, 2115-2122. [CrossRef] [PubMed]

24. Price, T.J.; Peeters, M.; Kim, T.W.; Li, J.; Cascinu, S.; Ruff, P.; Suresh, A.S.; Thomas, A.; Tjulandin, S.; Zhang, K.; et al. Panitumumab versus cetuximab in patients with chemotherapy-refractory wild-type KRAS exon 2 metastatic colorectal cancer (ASPECCT): A randomised, multicentre, open-label, non-inferiority phase 3 study. Lancet Oncol. 2014, 15, 569-579. [CrossRef] 
25. Antonacopoulou, A.G.; Tsamandas, A.C.; Petsas, T.; Liava, A.; Scopa, C.D.; Papavassiliou, A.G.; Kalofonos, H.P. EGFR, HER-2 and COX-2 levels in colorectal cancer. Histopathology 2008, 53, 698-706. [CrossRef] [PubMed]

26. McKay, J.A.; Murray, L.J.; Curran, S.; Ross, V.G.; Clark, C.; Murray, G.I.; Cassidy, J.; McLeod, H.L. Evaluation of the epidermal growth factor receptor (EGFR) in colorectal tumours and lymph node metastases. Eur. J. Cancer 2002, 38, 2258-2264. [CrossRef]

27. Saltz, L.B.; Meropol, N.J.; Loehrer, P.J.S.; Needle, M.N.; Kopit, J.; Mayer, R.J. Phase II trial of cetuximab in patients with refractory colorectal cancer that expresses the epidermal growth factor receptor. J. Clin. Oncol. 2004, 22, 1201-1208. [CrossRef] [PubMed]

28. Hecht, J.R.; Mitchell, E.; Neubauer, M.A.; Burris, H.A., 3rd; Swanson, P.; Lopez, T.; Buchanan, G.; Reiner, M.; Gansert, J.; Berlin, J. Lack of correlation between epidermal growth factor receptor status and response to Panitumumab monotherapy in metastatic colorectal cancer. Clin. Cancer Res. 2010, 16, 2205-2213. [CrossRef] [PubMed]

29. Cunningham, D.; Humblet, Y.; Siena, S.; Khayat, D.; Bleiberg, H.; Santoro, A.; Bets, D.; Mueser, M.; Harstrick, A.; Verslype, C.; et al. Cetuximab monotherapy and cetuximab plus irinotecan in irinotecan-refractory metastatic colorectal cancer. N. Engl. J. Med. 2004, 351, 337-345. [CrossRef] [PubMed]

30. Graham, D.M.; Coyle, V.M.; Kennedy, R.D.; Wilson, R.H. Molecular subtypes and personalized therapy in metastatic colorectal cancer. Curr. Colorectal Cancer Rep. 2016, 12, 141-150. [CrossRef] [PubMed]

31. Amado, R.G.; Wolf, M.; Peeters, M.; Van Cutsem, E.; Siena, S.; Freeman, D.J.; Juan, T.; Sikorski, R.; Suggs, S.; Radinsky, R.; et al. Wild-type KRAS is required for panitumumab efficacy in patients with metastatic colorectal cancer. J. Clin. Oncol. 2008, 26, 1626-1634. [CrossRef] [PubMed]

32. Peeters, M.; Kafatos, G.; Taylor, A.; Gastanaga, V.M.; Oliner, K.S.; Hechmati, G.; Terwey, J.-H.; van Krieken, J.H. Prevalence of RAS mutations and individual variation patterns among patients with metastatic colorectal cancer: A pooled analysis of randomised controlled trials. Eur. J. Cancer 2015, 51, 1704-1713. [CrossRef] [PubMed]

33. Han, C.-B.; Li, F.; Ma, J.-T.; Zou, H.-W. Concordant KRAS mutations in primary and metastatic colorectal cancer tissue specimens: A meta-analysis and systematic review. Cancer Investig. 2012, 30, 741-747. [CrossRef] [PubMed]

34. Loupakis, F.; Ruzzo, A.; Cremolini, C.; Vincenzi, B.; Salvatore, L.; Santini, D.; Masi, G.; Stasi, I.; Canestrari, E.; Rulli, E.; et al. KRAS codon 61, 146 and BRAF mutations predict resistance to cetuximab plus irinotecan in KRAS codon 12 and 13 wild-type metastatic colorectal cancer. Br. J. Cancer 2009, 101, 715-721. [CrossRef] [PubMed]

35. Sorich, M.J.; Wiese, M.D.; Rowland, A.; Kichenadasse, G.; McKinnon, R.A.; Karapetis, C.S. Extended RAS mutations and anti-EGFR monoclonal antibody survival benefit in metastatic colorectal cancer: A meta-analysis of randomized, controlled trials. Ann. Oncol. 2015, 26, 13-21. [CrossRef] [PubMed]

36. Van Cutsem, E.; Kohne, C.H.; Lang, I.; Folprecht, G.; Nowacki, M.P.; Cascinu, S.; Shchepotin, I.; Maurel, J.; Cunningham, D.; Tejpar, S.; et al. Cetuximab plus irinotecan, fluorouracil, and leucovorin as first-line treatment for metastatic colorectal cancer: Updated analysis of overall survival according to tumor KRAS and BRAF mutation status. J. Clin. Oncol. 2011, 29, 2011-2019. [CrossRef] [PubMed]

37. Bokemeyer, C.; Bondarenko, I.; Hartmann, J.T.; de Braud, F.; Schuch, G.; Zubel, A.; Celik, I.; Schlichting, M.; Koralewski, P. Efficacy according to biomarker status of cetuximab plus FOLFOX-4 as first-line treatment for metastatic colorectal cancer: The OPUS study. Ann. Oncol. Off. J. Eur. Soc. Med. Oncol. 2011, 22, 1535-1546. [CrossRef] [PubMed]

38. Bokemeyer, C.; van Cutsem, E.; Rougier, P.; Ciardiello, F.; Heeger, S.; Schlichting, M.; Celik, I.; Köhne, C.H. Addition of cetuximab to chemotherapy as first-line treatment for KRAS wild-type metastatic colorectal cancer: Pooled analysis of the CRYSTAL and OPUS randomised clinical trials. Eur. J. Cancer 2012, 48, 1466-1475. [CrossRef] [PubMed]

39. De Roock, W.; Jonker, D.J.; di Nicolantonio, F.; Sartore-Bianchi, A.; Tu, D.; Siena, S.; Lamba, S.; Arena, S.; Frattini, M.; Piessevaux, H.; et al. Association of KRAS p.G13D mutation with outcome in patients with chemotherapy-refractory metastatic colorectal cancer treated with cetuximab. JAMA 2010, 304, 1812-1820. [CrossRef] [PubMed] 
40. Tejpar, S.; Celik, I.; Schlichting, M.; Sartorius, U.; Bokemeyer, C.; van Cutsem, E. Association of KRAS G13D tumor mutations with outcome in patients with metastatic colorectal cancer treated with first-line chemotherapy with or without cetuximab. J. Clin. Oncol. 2012, 30, 3570-3577. [CrossRef] [PubMed]

41. Segelov, E.; Thavaneswaran, S.; Waring, P.M.; Desai, J.; Robledo, K.P.; Gebski, V.J.; Elez, E.; Nott, L.M.; Karapetis, C.S.; Lunke, S.; et al. Response to cetuximab with or without irinotecan in patients with refractory metastatic colorectal cancer harboring the KRAS G13D mutation: Australasian gastro-intestinal trials group ICECREAM study. J. Clin. Oncol. 2016, 34, 2258-2264. [CrossRef] [PubMed]

42. Lenz, H.J.; Niedzwiecki, D.; Innocenti, F.; Blanke, C.; Mahony, M.R.; O’Neil, B.H.; Shaw, J.E.; Polite, B.; Hochster, H.; Atkins, J.; et al. CALGB/SWOG 80405: Phase III trial of FOLFIRI or mFOLFOX6 with bevacizumab or cetuximab for patients with expanded RAS analyses in untreated metastatic adenocarcinoma of the colon or rectum. Ann. Oncol. 2014, 32, 5.

43. Schwartzberg, L.S.; Rivera, F.; Karthaus, M.; Fasola, G.; Canon, J.L.; Hecht, J.R.; Yu, H.; Oliner, K.S.; Go, W.Y. PEAK: A randomized, multicenter phase II study of panitumumab plus modified fluorouracil, leucovorin, and oxaliplatin (mFOLFOX6) or bevacizumab plus mFOLFOX6 in patients with previously untreated, unresectable, wild-type KRAS exon 2 metastatic colorectal. J. Clin. Oncol. 2014, 32, 2240-2247. [CrossRef] [PubMed]

44. Heinemann, V.; Rivera, F.; O’Neil, B.H.; Stintzing, S.; Koukakis, R.; Terwey, J.H.H.; Douillard, J.Y.Y. A study-level meta-analysis of efficacy data from head-to-head first-line trials of epidermal growth factor receptor inhibitors versus bevacizumab in patients with RAS wild-type metastatic colorectal cancer. Eur. J. Cancer 2016, 67, 11-20. [CrossRef] [PubMed]

45. Yoshino, T.; Uetake, H.; Tsuchihara, K.; Shitara, K.; Yamazaki, K.; Oki, E.; Sato, T.; Naitoh, T.; Komatsu, Y.; Takeshi, K.; et al. PARADIGM study: A multicenter, randomized, phase III study of 5-fluorouracil, leucovorin, and oxaliplatin (mFOLFOX6) plus panitumumab or bevacizumab as first-line treatment in patients with RAS (KRAS/NRAS) wild-type metastatic colorectal cancer. J. Clin. Oncol. 2016, 34, TPS776. [CrossRef]

46. Papagiorgis, P.C. Segmental distribution of some common molecular markers for colorectal cancer (CRC): Influencing factors and potential implications. Tumor Biol. 2016, 37, 5727-5734. [CrossRef] [PubMed]

47. Shen, H. Different treatment strategies and molecular features between right-sided and left-sided colon cancers. World J. Gastroenterol. 2015, 21, 6470. [CrossRef] [PubMed]

48. Ciombor, K.K.; Goldberg, R.M. Primary tumor sidedness as prognostic and predictive biomarker in metastatic colorectal cancer. JAMA Oncol. 2016. [CrossRef] [PubMed]

49. Hamada, H.; Meno, C.; Watanabe, D.; Saijoh, Y. Establishment of vertebrate left-right asymmetry. Nat. Rev. Genet. 2002, 3, 103-113. [CrossRef] [PubMed]

50. Tejpar, S.; Stintzing, S.; Ciardiello, F.; Tabernero, J.; Van Cutsem, E.; Beier, F.; Esser, R.; Lenz, H.-J.; Heinemann, V. Prognostic and predictive relevance of primary tumor location in patients with ras wild-type metastatic colorectal cancer retrospective analyses of the CRYSTAL and FIRE-3 Trials. JAMA Oncol. 2016. [CrossRef]

51. Petrelli, F.; Tomasello, G.; Borgonovo, K.; Ghidini, M.; Turati, L.; Dallera, P.; Passalacqua, R.; Sgroi, G.; Barni, S. Prognostic survival associated with left-sided vs. right-sided colon cancer. JAMA Oncol. 2016. [CrossRef] [PubMed]

52. Lee, M.; Advani, S.; Morris, J.; Jiang, Z.; Manyam, G.; Menter, D.; Broom, B.; Eng, C.; Overman, M.; Maru, D.; et al. Association of primary $\left(1^{\circ}\right)$ site and molecular features with progression-free survival (PFS) and overall survival (OS) of metastatic colorectal cancer (mCRC) after anti-epidermal growth factor receptor $(\alpha E G F R)$ therapy. J. Clin. Oncol. 2016, 34, 3506.

53. Ciardiello, F.; Tortora, G.; Magrassi, S.F.; Lanzara, A. EGFR antagonists in cancer treatment. N. Engl. J. Med. 2008, 358, 1160-1174. [CrossRef] [PubMed]

54. Morelli, M.P.; Overman, M.J.; Dasari, A.; Kazmi, S.M.A.; Mazard, T.; Vilar, E.; Morris, V.K.; Lee, M.S.; Herron, D.; Eng, C.; et al. Characterizing the patterns of clonal selection in circulating tumor DNA from patients with colorectal cancer refractory to anti-EGFR treatment. Ann. Oncol. 2015, 26, 731-736. [CrossRef] [PubMed]

55. Diaz, L.A., Jr.; Williams, R.T.; Wu, J.; Kinde, I.; Hecht, J.R.; Berlin, J.; Allen, B.; Bozic, I.; Reiter, J.G.; Nowak, M.A.; et al. The molecular evolution of acquired resistance to targeted EGFR blockade in colorectal cancers. Nature 2012, 486, 4-7. [CrossRef] [PubMed] 
56. Taly, V.; Pekin, D.; Benhaim, L.; Kotsopoulos, S.K.; Le Corre, D.; Li, X.; Atochin, I.; Link, D.R.; Griffiths, A.D.; Pallier, K.; et al. Multiplex picodroplet digital PCR to detect KRAS mutations in circulating DNA from the plasma of colorectal cancer patients. Clin. Chem. 2013, 59, 1722-1731. [CrossRef] [PubMed]

57. Bettegowda, C.; Sausen, M.; Leary, R.J.; Kinde, I.; Wang, Y.; Agrawal, N.; Bartlett, B.R.; Wang, H.; Luber, B.; Alani, R.M.; et al. Detection of circulating tumor DNA in early- and late-stage human malignancies. Sci. Transl. Med. 2014, 6, 224ra24. [CrossRef] [PubMed]

58. Montagut, C.; Dalmases, A.; Bellosillo, B.; Crespo, M.; Pairet, S.; Iglesias, M.; Salido, M.; Gallen, M.; Marsters, S.; Tsai, S.P.; et al. Identification of a mutation in the extracellular domain of the epidermal growth factor receptor conferring cetuximab resistance in colorectal cancer. Nat. Med. 2012, 18, 221-223. [CrossRef] [PubMed]

59. Dienstmann, R.; Patnaik, A.; Garcia-Carbonero, R.; Cervantes, A.; Benavent, M.; Rosello, S.; Tops, B.B.J.; van der Post, R.S.; Argiles, G.; Skartved, N.J.; et al. Safety and activity of the first-in-class Sym004 anti-EGFR antibody mixture in patients with refractory colorectal cancer. Cancer Discov. 2015, 5, 598-609. [CrossRef] [PubMed]

60. Pedersen, M.W.; Jacobsen, H.J.; Koefoed, K.; Hey, A.; Pyke, C.; Haurum, J.S.; Kragh, M. Sym004: A novel synergistic anti-epidermal growth factor receptor antibody mixture with superior anticancer efficacy. Cancer Res. 2010, 70, 588-597. [CrossRef] [PubMed]

61. Koefoed, K.; Steinaa, L.; Soderberg, J.N.; Kjaer, I.; Jacobsen, H.J.; Meijer, P.-J.; Haurum, J.S.; Jensen, A.; Kragh, M.; Andersen, P.S.; et al. Rational identification of an optimal antibody mixture for targeting the epidermal growth factor receptor. MAbs 2011, 3, 584-595. [CrossRef] [PubMed]

62. Iida, M.; Brand, T.M.; Starr, M.M.; Li, C.; Huppert, E.J.; Luthar, N.; Pedersen, M.W.; Horak, I.D.; Kragh, M.; Wheeler, D.L. Sym004, a novel EGFR antibody mixture, can overcome acquired resistance to cetuximab. Neoplasia 2013, 15, 1196-1206. [CrossRef] [PubMed]

63. Hanna, D.L.; Lenz, H.-J. Novel therapeutics in metastatic colorectal cancer: Molecular insights and pharmacogenomic implications. Expert Rev. Clin. Pharmacol. 2016, 2433, 1-18. [CrossRef] [PubMed]

64. Kearns, J.D.; Bukhalid, R.; Sevecka, M.; Tan, G.; Gerami-Moayed, N.; Werner, S.L.; Kohli, N.; Burenkova, O.; Sloss, C.M.; King, A.M.; et al. Enhanced targeting of the EGFR network with MM-151, an oligoclonal anti-EGFR antibody therapeutic. Mol. Cancer Ther. 2015, 14, 1625-1636. [CrossRef] [PubMed]

65. Arena, S.; Siravegna, G.; Mussolin, B.; Kearns, J.D.; Wolf, B.B.; Misale, S.; Lazzari, L.; Bertotti, A.; Trusolino, L.; Adjei, A.A.; et al. MM-151 overcomes acquired resistance to cetuximab and panitumumab in colorectal cancers harboring EGFR extracellular domain mutations. Sci. Transl. Med. 2016, 8, 324ra14. [CrossRef] [PubMed]

66. Lieu, C.; Harb, W.; Beeram, M.; Power, P.; Kearns, J.; Nering, R.; Moyo, V.; Wolf, B.; Adjei, A. Phase 1 trial of MM-151, a novel oligoclonal anti-EGFR antibody combination in patients with refractory solid tumors. J. Clin. Oncol. 2014, 32, 2518.

67. Martincorena, I.; Campbell, P.J. Somatic mutation in cancer and normal cells. Science 2015, 349, $1483-1489$. [CrossRef] [PubMed]

68. Therkildsen, C.; Bergmann, T.K.; Henrichsen-Schnack, T.; Ladelund, S.; Nilbert, M. The predictive value of KRAS, NRAS, BRAF, PIK3CA and PTEN for anti-EGFR treatment in metastatic colorectal cancer: A systematic review and meta-analysis. Acta Oncol. 2014, 53, 852-864. [CrossRef] [PubMed]

69. Misale, S.; di Nicolantonio, F.; Sartore-Bianchi, A.; Siena, S.; Bardelli, A. Resistance to anti-EGFR therapy in colorectal cancer: From heterogeneity to convergent evolution. Cancer Discov. 2014, 4, 1269-1280. [CrossRef] [PubMed]

70. Takahashi, N.; Yamada, Y.; Furuta, K.; Honma, Y.; Iwasa, S.; Takashima, A.; Kato, K.; Hamaguchi, T.; Shimada, Y. Serum levels of hepatocyte growth factor and epiregulin are associated with the prognosis on anti-EGFR antibody treatment in KRAS wild-type metastatic colorectal cancer. Br. J. Cancer 2014, 110, 2716-2727. [CrossRef] [PubMed]

71. Inno, A.; di Salvatore, M.; Cenci, T.; Martini, M.; Orlandi, A.; Strippoli, A.; Ferrara, A.M.; Bagal, C.; Cassano, A.; Larocca, L.M.; et al. Is there a role for IGF1R and c-MET pathways in resistance to cetuximab in metastatic colorectal cancer? Clin. Colorectal Cancer 2011, 10, 325-332. [CrossRef] [PubMed]

72. Bardelli, A.; Corso, S.; Bertotti, A.; Hobor, S.; Valtorta, E.; Siravegna, G.; Sartore-Bianchi, A.; Scala, E.; Cassingena, A.; Zecchin, D.; et al. Amplification of the MET receptor drives resistance to anti-EGFR therapies in colorectal cancer. Cancer Discov. 2013, 3, 658-673. [CrossRef] [PubMed] 
73. Yonesaka, K.; Zejnullahu, K.; Okamoto, I.; Satoh, T.; Cappuzzo, F.; Souglakos, J.; Ercan, D.; Rogers, A.; Roncalli, M.; Takeda, M.; et al. Activation of ERBB2 signaling causes resistance to the EGFR-directed therapeutic antibody cetuximab. Sci. Transl. Med. 2011, 3, 99ra86. [CrossRef] [PubMed]

74. Bertotti, A.; Migliardi, G.; Galimi, F.; Sassi, F.; Torti, D.; Isella, C.; Corà, D.; di Nicolantonio, F.; Buscarino, M.; Petti, C.; et al. A molecularly annotated platform of patient- derived xenografts ("xenopatients") identifies HER2 as an effective therapeutic target in cetuximab-resistant colorectal cancer. Cancer Discov. 2011, 1, 508-523. [CrossRef] [PubMed]

75. Takegawa, N.; Yonesaka, K.; Sakai, K.; Ueda, H.; Watanabe, S.; Nonagase, Y.; Okuno, T.; Takeda, M.; Maenishi, O.; Tsurutani, J.; et al. HER2 genomic amplification in circulating tumor DNA from patients with cetuximab-resistant colorectal cancer. Oncotarget 2016, 7, 3453-3460. [CrossRef] [PubMed]

76. Siravegna, G.; Mussolin, B.; Buscarino, M.; Corti, G.; Cassingena, A.; Crisafulli, G.; Ponzetti, A.; Cremolini, C.; Amatu, A.; Lauricella, C.; et al. Clonal evolution and resistance to EGFR blockade in the blood of colorectal cancer patients. Nat. Med. 2015, 21, 795-801. [CrossRef] [PubMed]

77. Davies, H.; Bignell, G.R.; Cox, C.; Stephens, P.; Edkins, S.; Clegg, S.; Teague, J.; Woffendin, H.; Garnett, M.J.; Bottomley, W.; et al. Mutations of the BRAF gene in human cancer. Nature 2002, 417, 949-954. [CrossRef] [PubMed]

78. Yokota, T.; Ura, T.; Shibata, N.; Takahari, D.; Shitara, K.; Nomura, M.; Kondo, C.; Mizota, A.; Utsunomiya, S.; Muro, K.; et al. BRAF mutation is a powerful prognostic factor in advanced and recurrent colorectal cancer. Br. J. Cancer 2011, 104, 856-862. [CrossRef] [PubMed]

79. Di Nicolantonio, F.; Martini, M.; Molinari, F.; Sartore-Bianchi, A.; Arena, S.; Saletti, P.; de Dosso, S.; Mazzucchelli, L.; Frattini, M.; Siena, S.; et al. Wild-type BRAF is required for response to panitumumab or cetuximab in metastatic colorectal cancer. J. Clin. Oncol. 2008, 26, 5705-5712. [CrossRef] [PubMed]

80. Samatar, A.A.; Poulikakos, P.I. Targeting RAS-ERK signalling in cancer: Promises and challenges. Nat. Rev. Drug Discov. 2014, 13, 928-942. [CrossRef] [PubMed]

81. Rajagopalan, H.; Bardelli, A.; Lengauer, C.; Kinzler, K.W.; Vogelstein, B.; Velculescu, V.E. Tumorigenesis: RAF/RAS oncogenes and mismatch-repair status. Nature 2002, 418, 934. [CrossRef] [PubMed]

82. Chapman, P.B.; Hauschild, A.; Robert, C.; Haanen, J.B.; Ascierto, P.; Larkin, J.; Dummer, R.; Garbe, C.; Testori, A.; Maio, M.; et al. Improved survival with vemurafenib in melanoma with BRAF ${ }^{\mathrm{V} 600 \mathrm{E}}$ mutation. N. Engl. J. Med. 2011, 364, 2507-2516. [CrossRef] [PubMed]

83. Hauschild, A.; Grob, J.-J.; Demidov, L.V.; Jouary, T.; Gutzmer, R.; Millward, M.; Rutkowski, P.; Blank, C.U.; Miller, W.H.J.; Kaempgen, E.; et al. Dabrafenib in BRAF-mutated metastatic melanoma: A multicentre, open-label, phase 3 randomised controlled trial. Lancet (London, England) 2012, 380, 358-365. [CrossRef]

84. Lito, P.; Pratilas, C.A.; Joseph, E.W.; Tadi, M.; Halilovic, E.; Zubrowski, M.; Huang, A.; Wong, W.L.; Callahan, M.K.; Merghoub, T.; et al. Relief of profound feedback inhibition of mitogenic signaling by RAF inhibitors attenuates their activity in $\mathrm{BRAF}^{\mathrm{V} 600 \mathrm{E}}$ melanomas. Cancer Cell 2012, 22, 668-682. [CrossRef] [PubMed]

85. Corcoran, R.; André, T.; Yoshino, T.; Bendell, J.; Atreya, C.; Schellens, J.; Ducreux, M.; McRee, A.; Siena, S.; Middleton, G.; et al. Efficacy and circulating tumor DNA (ctDNA) analysis of the BRAF inhibitor dabrafenib (D), MEK inhibitor trametinib (T), and anti-EGFR antibody panitumumab (P) in patients (pts) with BRAF V600E-mutated (BRAFm) metastatic colorectal cancer (mCRC). Ann Oncol. 2016, 27, 4550. [CrossRef]

86. Corcoran, R.B.; Ebi, H.; Turke, A.B.; Coffee, E.M.; Nishino, M.; Cogdill, A.P.; Brown, R.D.; Della Pelle, P.; Dias-Santagata, D.; Hung, K.E.; et al. EGFR-mediated re-activation of MAPK signaling contributes to insensitivity of BRAF mutant colorectal cancers to RAF inhibition with vemurafenib. Cancer Discov. 2012, 2, 227-235. [CrossRef] [PubMed]

87. Yang, H.; Higgins, B.; Kolinsky, K.; Packman, K.; Bradley, W.D.; Lee, R.J.; Schostack, K.; Simcox, M.E.; Kopetz, S.; Heimbrook, D.; et al. Antitumor activity of BRAF inhibitor vemurafenib in preclinical models of BRAF-mutant colorectal cancer. Cancer Res. 2012, 72, 779-789. [CrossRef] [PubMed]

88. Corcoran, R.B.; Atreya, C.E.; Falchook, G.S.; Kwak, E.L.; Ryan, D.P.; Bendell, J.C.; Hamid, O.; Messersmith, W.A.; Daud, A.; Kurzrock, R.; et al. Combined BRAF and MEK inhibition with dabrafenib and trametinib in BRAF V600-mutant colorectal cancer. J. Clin. Oncol. 2015, 33, 4023-4031. [CrossRef] [PubMed]

89. Yaeger, R.; Cercek, A.; O’Reilly, E.; Reidy, D.; Kemeny, N.; Wolinsky, T.; Gollub, M.; Lacouture, M.; Rosen, N.; Vakiani, E.; et al. Pilot study of vemurafenib and panitumumab combination therapy in patients with $\mathrm{BRAF}^{\mathrm{V} 600 \mathrm{E}}$ mutated metastatic colorectal cancer. J. Clin. Oncol. 2015, 33, 611. [CrossRef] 
90. Tabernero, J.; Geel, R.; Guren, T.; Yaeger, R.; Spreafico, A.; Faris, J.; Yoshino, T.; Yamada, Y.; Kim, T.; Bendell, J.; et al. Phase 2 results: Encorafenib (ENCO) and cetuximab (CETUX) with or without alpelisib (ALP) in patients with advanced BRAF-mutant colorectal cancer (BRAFm CRC). J. Clin. Oncol. 2016, 34, 3544.

91. Kopetz, S.; McDonough, S.; Morris, V.; Lenz, H.; Magliocco, A.; Atreya, C.; Diaz, L.; Allegra, C.; Wang, S.; Lieu, C.; et al. Randomized trial of irinotecan and cetuximab with or without vemurafenib in BRAF-mutant metastatic colorectal cancer (SWOG 1406). J. Clin. Oncol. 2017, 35 (Suppl. S4), 520. [CrossRef]

92. Ahronian, L.G.; Sennott, E.M.; van Allen, E.M.; Wagle, N.; Kwak, E.L.; Faris, J.E.; Godfrey, J.T.; Nishimura, K.; Lynch, K.D.; Mermel, C.H.; et al. Clinical acquired resistance to RAF inhibitor combinations in BRAF-mutant colorectal cancer through MAPK pathway alterations. Cancer Discov. 2015, 5, 358-367. [CrossRef] [PubMed]

93. Kopetz, S.; Desai, J.; Chan, E.; Hecht, J.R.; O’Dwyer, P.J.; Maru, D.; Morris, V.; Janku, F.; Dasari, A.; Chung, W.; et al. Phase II pilot study of vemurafenib in patients with metastatic braf-mutated colorectal cancer. J. Clin. Oncol. 2015, 33, 4032-4038. [CrossRef] [PubMed]

94. Hyman, D.M.; Puzanov, I.; Subbiah, V.; Faris, J.E.; Chau, I.; Blay, J.-Y.; Wolf, J.; Raje, N.S.; Diamond, E.L.; Hollebecque, A.; et al. Vemurafenib in multiple nonmelanoma cancers with BRAFV600 mutations. N. Engl. J. Med. 2015, 373, 726-736. [CrossRef] [PubMed]

95. Hochster, H.; Messersmith, W.; O’Neil, B.; Groshen, S.; Cohen, D.; Denlinger, C.; Gold, P.; Eckhardt, S.; Locker, G.; Ames, P.; et al. Second-line therapy of KRAS-mutated (KRASm) metastatic colorectal cancer (CRC) with the MEK inihibitor selumetinib ([SEL], AZ6244, ARRY-142886) in combination with irinotecan (IRI): An AGICC study. J. Clin. Oncol. 2013, 31, 380. [CrossRef]

96. Eng, C.; Hart, L.; Severtsev, A.; Gladkov, O.; Mueller, L.; Kopp, M.; Vladimirov, V.; Langdon, R.; Kotiv, B.; Barni, S.; et al. A randomized, placebo-controlled, phase I/II study of tivantinib (ARQ 197) in combination with cetuximab and irinotecan in patients (pts) with KRAS wild-type (WT) metastatic colorectal cancer (CRC) who had received previous front-line systemic therapy. J. Clin. Oncol. 2013, 31, 3508.

(c) 2017 by the authors. Licensee MDPI, Basel, Switzerland. This article is an open access article distributed under the terms and conditions of the Creative Commons Attribution (CC BY) license (http:/ / creativecommons.org/licenses/by/4.0/). 